\author{
REVIEW OF EUROPEAN AND COMPARATIVE LAW \\ VOLUME XLIV \\ YEAR 2021, ISSUE 1, pp. 37-52 \\ DOI: https://doi.org/10.31743/recl.11162
}

\title{
COUNCILLOR CLUBS IN COMMUNES IN POLAND AND FRANCE
}

\author{
Monika Augustyniak*
}

\begin{abstract}
The article presents the legal status of councillor clubs in Poland and in France. It discusses establishment and functioning of clubs that are usually created on the basis of political criteria, in the light of a councillor's free mandate and social control. It presents elements of club's financing and possibility to express opinions by minority clubs in a council. The analysis of the legal status of councillor clubs leads to conclusions and determination of the direction of changes in the scope of the research concerned.

The legal status of councillor clubs corresponds to the issue of quality of democratisations of a self-governing authority. Therefore, specification of premises determining organisation and operation of councillor clubs in a municipal council is a significant regime-related issue. The problems related to functioning of the councillor clubs in the Polish and French legal orders is currently a challenge for contemporary local self-government.
\end{abstract}

Keywords: councillor clubs, councillor's free mandate, social control

Research project executed at the Department of Law, Administration and International Relations of Andrzej Frycz Modrzewski Krakow University, financed with funds devoted to its statutory activity on the basis of the decision no WPAiSM/DS/1/2020.

Dr. habil. Monika Augustyniak, Associate Professor of KAAFM, Faculty of Law, Administration and International Relations, Andrzej Frycz Modrzewski Krakow University; correspondence address: Gustawa Herlinga-Grudzińskiego 1, 30-705 Kraków, Poland; e-mail: monikaaugustyniak1@gmail.com; https://orcid.org/0000-0001-6196-1989. 


\section{INTRODUCTION}

The subject of interest of this article covers the legal status of councillor clubs in communes in Poland and in France. An interesting issue is to determine the relationship between a free mandate of a councillor resulting directly from the provisions concerning regime in the acts on local governments and the actual de iure legal status of a commune councillor. This analysis leads to conclusions and determination of the direction of changes in the scope of the research concerned.

The legal status of a councillor of an entity of local self-government is one of the central issues of contemporary local government. It corresponds to the issue of quality of democratisations of a self-governing authority. Therefore, specification of premises determining organisation and operation of councillor clubs in a commune council is a significant regime-related issue and its discussion will lead to a reflection on the legal status of a councillor in Polish local self-government. A need of change in regulations on organisation, operation and funding of councillor clubs is currently a challenge for contemporary local self-government.

Legal dogmatic and comparative legal methods have been used in this article.

\section{ESTABLISHMENT AND INTERNAL ORGANISATION OF COUNCILLOR}

\section{CLUBS IN COMMUNES IN THE POLISH AND FRENCH LEGAL ORDERS}

The Polish legal order, according to article $23 \mathrm{sec} .2$ of the Act on Commune Self-Government, provides for a possibility to establish councillor clubs under principles defined in the charter of a given commune ${ }^{1}$. A commune councillor is not obliged to establish and belong to a club. However, if they wish to do so, a commune charter should give them such a possibility. Establishment of a club and participation in it should result from values that are approved by the law, preferred by a councillor and that aim at the welfare of the community. This is the way how the legis-

1 The Act on Municipal Self-Government of 8 March 1990, Journal of Laws 2020, item 713, as amended, hereinafter AMSG. 
lator enables fulfilment of a human right to freedom of assembly in order to enhance the possibility of operation of a single councillor. A councillor club is established according to certain criteria allowed by law, including political ones ${ }^{2}$. The legal grounds of operation of a club comprise not only the act on local self-government and a charter of a given commune, but also regulation of a given club. The regulation is not subject to approval by the municipal authorities. Furthermore, it is not evaluated by the voivode within the scope of control and supervision.

In the French legal order, the existence of councillor clubs in a decision making body is regulated by the provisions of the General Code of Territorial Communities (Code général des collectivités territoriales or $\mathrm{CGCT}^{3}$ ) and the internal provisions of a municipal council (conseil municipal). The organisation and operation of the municipal council is governed by the council's internal regulation that should be adopted within 6 months from election of the council (this provision is binding for communes comprising at least 3,500 inhabitants - see article L. 2541-5 CGCT). The regulation of a previous council is applicable until the date of adoption of a new regulation. If the chairperson of a council refuses to provide a regulation to the council for the purpose of its adoption, it will be an act of abuse of authority, arrogation of powers ${ }^{4}$. Communes above 3,500 inhabitants are obliged to adopt regulations of internal operations of a municipal council for a term of office. In small communes, below 3,500 inhabitants, adoption of the above regulation is optional. The regulation defines, for instance, the rights of councillors belonging to clubs and of minority groups in a council ${ }^{5}$. This act may be challenged in the administrative court ${ }^{6}$.

2 Supreme Administrative Court, Judgement of 12 May 2017, Ref. No. II OSK 2216/15, LEX no. 2321536.

3 Code général des collectivités territoriales (General Code of Territorial Communities, CGCT) - source: https://www.legifrance.gouv.fr.

4 Rep. min. no 42396, JOAN Q.1er mai 2000, p. 2751 - see Philippe Lacaïle, Lélu municipal. Statut de l'élu et foncionnement du conseil municipal (Paris: Berger-Levraut, 2014), 173.

5 See Jacques Ferstenbert, François Priet, and Paule Quilichini, Droit des collectivités territoriales (Paris: Dalloz, 2016), 247.

6 See CE Sect. 10 fevr. 1995, Riehl et Cne de Coudekerque-Branche c/Devos, Lebon, 66-67; GADD no. 13. 
Under CGCT provisions, a municipal council in its internal regulation should define in detail the following issues within the scope of the following three procedures:

- organisation of budget debate (article L. 2312-1 of CGCT);

- terms and conditions of consultations on contracts and public procurement (art. L. 2121-12 CGCT);

- terms and conditions of presentation of and replies to oral questions (art. L. 2121-19 CGCT).

According to article L2121-28 CGCT operation of the councillor clubs (des groupes d'élus) may be subject to resolutions of the municipal council, including the internal regulation of its operation. Unlike in the Act, these issues cannot govern regulation concerning allowances and prohibition of subsidising clubs. In this context, it is necessary to maintain the rights related to the mandate of an individual councillor in the provisions of the regulation, such as the right to information and the right to speak that cannot be combined with club membership. As an example, the councillor's rights to ask oral questions should be mentioned. Councillors have the right to ask oral questions (questions orales) on issues related to a given municipal community. This provision does not refer to councillor clubs, because this right is connected only with retention of rights related to the mandate of an individual councillor, such as right to information and speech, which cannot be connected de iure with club membership .

Both in the Polish and French legal orders, councillor clubs are closely related to functioning of the commune's decision making body, so the municipal council /conseil municipal defines the principles of operation of councillor clubs, which in fact leads to their subordination to the decision making body in the council. However, a councillor club is neither the commune's authority, nor its assisting authority ${ }^{8}$. Therefore, the club's status cannot be confused with the status of the council's commission?

CAA Lyon, 7 mars 2013, n² 12 LY01424.

8 See Paweł Chmielnicki, "Komentarz do art. 23," in Ustawa o samorzadzie gminnym. Komentarz, ed. Paweł Chmielnicki (Warsaw: LexisNexis, 2010), 312.

9 See Czesław Martysz, "Komentarz do art. 23," in Ustawa o samorzadzie gminnym. Komentarz, ed. Bogdan Dolnicki (Warsaw: WoltersKluwer, 2018), 379. 
Clubs are used by a councillor to maintain regular relations with inhabitants and their organisations, in particular to acknowledge demands raised by commune inhabitants. A club performs an advisory function for a councillor. It helps a councillor to focus on the welfare of commune's self-governmental community. It is an indicator of respect of the borders of the institution of councillor's free mandate that means that a councillor represents the entire self-governmental community, while bearing only the political liability for exercising of their mandate. An assessment of the councillor's activities takes place during the next local elections. It is the case of both Polish and French legal orders. In the case law of the administrative courts it is pointed out that since the electorate cannot restrict the councillor's freedom in exercising of a mandate, either the municipal council cannot apply any disciplinary measures in case of an unreliable councillor if they do not fulfil the obligation to participate in the works of the council and its internal bodies ${ }^{10}$. However, councillor's absence from work of the municipal bodies is connected with financial issues, that is reduction of allowances in result to their absence from meetings of the bodies, where a given councillor was elected for. It is significant that a councillor does not make statements and does not give consent for election to a specific commission. In its judgement dated 26 November 2019, the Supreme Administrative Court stated that no provisions of the mandatory legislation imposes an obligation on the municipal council to receive a statement from a councillor that they agree on being a candidate for a member of a specific commission. However, it should be taken into account that a councillor should focus mainly on the welfare of commune's self-governmental community, and according to the oath, they should fulfil their obligations fairly and reliably. A councillor should actively participate in work of the council and a commission, act in the interest of local community, focusing on the welfare of self-governmental community, leaving aside their own interests or the interests of their political parties in favour of public activities ${ }^{11}$.

10 Provincial Administrative Court in Warsaw, Judgement of 15 January 2015 r., Ref. No. II SA/Wa 1837/14, LEX no. 1748270.

11 Supreme Administrative Court, Judgement of 26 November 2019, Ref. No. II OSK 2672/19, LEX no. 2778148. 
But the club membership entails a statement given by the respective councillor on participation in the work of a given club. Such consent must be explicit, because it can impact on rights of clubs, e.g. in respect to presentation of resolutions or appointment of a club representative to mandatory standing committees of the council.

The charter of a council cannot limit a councillor in their freedom to associate in councillor clubs, that is in fulfilment of their tasks and obligations. A council cannot impose an obligation on a councillor to be a member of a specific club, although the legislator makes it indirectly since the composition of two standing committees (the audit committee and the complaint, motion and petition committee) depend on memberships in clubs of the members of the decision making body. Clubs most often reflect the political composition of a council, although increasingly more often groups of councillors appear under a name of a club that gather councillors in order to introduce a specific social or ecological initiative.

The Polish legislator defined the minimum number of club members, pointing out that a councillor club shall be established by at least 3 councillors, which means that the provisions of a commune charter may determine limits of persons belonging to a club, but not the minimum amount of members of a given club. While establishing a club, the municipal council should take account of the councillor's right of freedom to associate in freely established clubs, and thus it should take account of the reality, including the number of members of a council and the social and political relations in it. ${ }^{12}$

The legislator pointed out to voluntary establishment of clubs in the decision making body but decided that the members of two mandatory committees in the council have to reflect representatives of clubs. According to article $18 \mathrm{a}$ sec. 2 of ANSG, the review committee consists of councillors, including representatives of all clubs, expect of councillors who hold positions of chairperson and deputy chairpersons of the council. Similar regulation refers to the members of the complaint, motion and petition committee appointed in compliance with the amendment

12 Supreme Administrative Court, Judgement of 14 November 2017, Ref. No. II OSK 427/16, LEX no. 2469400. 
of $2018^{13}$. In the judgement dated 17 April 2019, the Voivodeship Administrative Court in Szczecin pointed out that a resolution preventing a councillor club from having a representative in the compliant, motion and petition committee is contradictory to legal provisions, and that is invalid. No legal provision binds an assessment of results of violation of a requirement concerning members of a committee with examination of circumstances pointing out to good or bad will of the decision making body ${ }^{14}$.

Non-attached councillors may also participate in works of these two committees, but it does not balance the privileged position of clubs in respect to the membership of two key committees in the municipal council ${ }^{15}$.

The regulation of a club defines bodies of a club, e.g. a meeting of club members, chairperson of a club and a secretary. It also determines the scope of their activities, as well as forms and modes of adopting resolution and presenting opinions. Tasks of a chairperson of a club include providing the current list of club members to the chairperson of a council, which is important in respect to representation of clubs in works of the committees of a municipal council. The chairperson of a council keeps a register of clubs, where the data provided in such notification are recorded.

The chairperson of a club prepares and chairs club meetings. He/she presents draft opinions and co-ordinates the work of a club in the municipal council and its committees. He/she runs the organisational and financial operations of a club.

In the French legal order councillors may establish clubs according to their political preferences. They consist of members who are registered or connected with a given club. The minimum number of club members depend on the provisions of the council's internal regulation, but usually it

13 Act of 11 January 2018 on amendment of some acts in order to increase the participation of citizens in the process of election, functioning and control of some public bodies (Journal of Laws 2018, item 130), hereinafter the amendment of 2018.

14 Provincial Administrative Court in Szczecin, Judgement of 17 April 2019, Ref. No. II SA/Sz 232/19, LEX no. 2655827.

15 See Monika Augustyniak, "O potrzebie odpolitycznienia samorządu gminnego marzenie normatywne," Samorzad Terytorialny, no. 7-8 (2020): 47. 
is at least 3 or 5 councillors $^{16}$. CGCT provisions do not regulate this issue, leaving it for a decision of a municipal council. Also, the issue of principles and mode of operation of clubs is subject to the provisions of the Council's internal regulation ${ }^{17}$.

Councillors may be members of a club or be non-attached with any club registered in the council. A councillor who is not a member of any club may join a club of non-attached councillors it if consists of at least three members or declare connection with a selected registered councillor club upon consent of the chairperson of such club. Councillor clubs and groups of non-attached councillors are reported to a mayor (the executive body of a commune) for the purpose of registration. Then the mayor informs the municipal council about it. Mayor's decision on refusal to acknowledge members of a given club may be appealed against in an administrative court.

It possible to be a member of one club only. A councillor club is established in result of a statement submitted to a mayor and signed by all members who wish to participate in the group of councillors concerned, together with a list of such persons and information of the chairperson of the club. The charter of the club enters into force after the document upon publication of the document in the "Official Municipal/Departmental Bulletin” ("Bulletin municipal/départemental officiel»). Documents shall be published promptly. All changes of members and a chairperson should be reported to the mayor in the same way for the purpose of publication. On the conditions defined by the council and within the limits defined by law, the mayor provides selected clubs with materials and human resources necessary for their operation. He/she equips the councillor clubs in the assisting apparatus ${ }^{18}$.

Space for information to be published by clubs is booked in every Public Information Bulletin that contains information on organisation and functioning of a municipal council and on the website of a given

16 CAA Nancy, 4 juin 1998, ADJA 1998, 885.

17 TA Paris 26 mars 1999, Mame, Dr. adm. 1999, 359.

18 See article 26 du Règlement adopté lors de la séance du Conseil municipal du 10 février 2015; https://www.fontenay-aux-roses.fr/975/reglement-interieur-du-conseil-municipal.htm, (access: 03.10.2020). See Philippe Lacaile, L'élu municipal. Statut de l'élu et foncionnement du conseil municipal (Paris: Berger-Levraut, 2014), 137. 
commune. As from the enactment of the Act of 27 February 2002 (Loi $\mathrm{n}^{\circ}$ 2002-276 du 27 février 2002 relative à la démocratie de proximitée ${ }^{19}$ ), communes with at least 3,500 inhabitants that publish a public information bulletin (Bulletin d'information générale) devoted to undertakings of a commune and its management, in any form, also in the Internet and on Facebook, are obliged to book space in it for the opposition, in particular for clubs of councillors from the opposition on the terms and conditions defined in the internal regulation (article L2121-27-1 CGCT). These issues are governed by the internal provisions of a municipal council. The right of councillors and councillor clubs to express own opinions cannot be restricted, in particular in the period of elections. Division of space in a municipal bulletin only on the basis of results of elections would not take account of possible changes in the distribution of power in the council between the majority and the opposition during a term of office ${ }^{20}$.

Local councillors elected in general elections, who fulfil their obligations in compliance with ethical rules defined in the Local Councillor Charter (Charte de l'élu local - this act is governed by article L. 1111-1-1 CGCT) ${ }^{21}$, should act according to those rules. The charter should be read out by the mayor or his/her representative at the initial meeting of the municipal council ${ }^{22}$. It reminds everyone about ethical obligations of elected councillors, which affects their activities in the council, committees and councillor clubs.

\section{FUNCTIONING OF COUNCILLOR CLUBS IN THE LIGHT}

OF THE FREE MANDATE OF A COUNCILLOR AND SOCIAL CONTROL IN POLAND AND IN FRANCE

The clubs in the Polish and French municipal self-government are used by councillors to maintain regular relations with inhabitants and their or-

19 Loi n 2002-276 du 27 février 2002 relative à la démocratie de proximité, NOR: INTX0100065L.

20 CCA Versailles 13 dec. 2007, M. Bellebeau, AJDA 2008, 894.

21 See Vincent Potier, Déontologie des élus et des fonctionnaires territoriaux (Paris: Dalloz, 2015), 200.

22 See Jean Waline, Droit administratif (Paris: Dalloz, 2018), 138. 
ganisations. They receive postulates and motions submitted by inhabitants of a commune, to present them further to municipal authorities for examination. Councillors are representatives of the electorate, inhabitants of a given local community and they represent local and public interests, but not their particular ones.

Pertaining to article L. 2121-13 of CGCT, every councillor has the right to be informed, within the scope of their mandates, on all issues concerning a commune that are subject to meetings of the council, which are accessible for the public. Although the provision refers to an individual councillor, it pointed out in the French literature that the interpretation of this article does not exclude application of this article to councillor clubs, provided that it does not restrict a non-attached councillor in exercising of the rights they have. ${ }^{23}$ There are some exceptions in this field, e.g. the institution of the councillor's oral question.

In the French legal order, preparation of an agenda of a meeting belongs to the scope of responsibilities of the executive body in a local community. It refers also to preparation of draft resolutions. In the internal regulations of councils, clubs have rights granted by the French body presenting draft resolutions, e.g. to request for suspension of a meeting of a council ${ }^{24}$. Councillor clubs may submit amendments to draft resolutions and present their opinions and motions on a session of a council within the scope of the issues discussed. They may also submit formal motions ${ }^{25}$. Every committee in a council elects a chairperson and a deputy chairperson of a committee, and such election should reflect political pluralism on a municipal council.

In the Polish legal order, under the amendment of 2018, the legislator is granted the right to a club to propose draft resolutions. A club may

23 See Nadia Ben Ayed, La constitution des groupes d'élus, Le Courrier des maires no. 282 Septembre 2014, https://www.seban-associes.avocat.fr/wp-content/uploads/2015/08/pub _cdm_groupesdelus.pdf.

24 See article 25 Règlement adopté lors de la séance du Conseil municipal du 10 février 2015; https://www.fontenay-aux-roses.fr/975/reglement-interieur-du-conseil-municipal.htm, (access: 03.10.2020).

25 See article 2 and article 5 Règlement intérieur du Conseil de Paris (Adopté lors de la séance des 4 au 6 février 2019 - 2019 DDCT 21), source: https://cdn.paris.fr/paris/2019/07/24/09e31f716a64d71503df2bcaba33620d.pdf. 
present a draft resolution on every issue, that is not subject to the exclusive competence of the executive body of a commune. Additional rights for clubs, that have been granted to them as from the new term of office of the council, are related to the obligation of council's chairpersons in respect to introduction of a draft resolution proposed by a club to the agenda. These provisions are to counteract blocking of drafts presented by councillors or councillor clubs by larger groups or the chairperson of the council who selects draft resolutions to be included in the agenda on a given session at his/her discretion. It gives real guarantees for exercising of councillor's free mandate.

At a request of a councillor club, the chairperson of the council introduces a draft resolution to the agenda of the next session of the decision making body, if it has been submitted by a councillor club, provided that it was received by the council at least 7 days before commencement of a session. In this manner every councillor club may propose not more than one draft resolution for every next session of a given municipal council. Thus, it should be stated that the legislator has privileged a councillor club in respect of proposing resolutions that are obligatorily introduced at its request to an agenda. Before, only the executive authority was entitled to use this mode. Failure to introduce a draft resolution proposed in this manner by a club to an agenda violates the provisions of the Act on Municipal Self-Government. It should be mentioned that these regulations refer only to introduction of a draft to an agenda, not the issue of voting that still remains the right of municipal councillors.

A councillor should be a member of one club only, although such prohibition is not directly expressed in the act. However, memberships of a councillor in more than one club may result in unreliability of exercising of the councillor's mandate and their participation in such committees of the council (the review committee, the complaint, petition and motion committee), where the representatives of all clubs are obliged to participate. The provisions of club regulations often prohibit memberships in other councillor clubs in case of members of a given club. The provisions in both legal orders are the same.

In both legal orders, a term of office of a club is the same as the term of office of the decision making body in a commune, because members of a club are councillors elected for the same term of office. The term of office 
of a council in Poland is 5 years, while in France -6 years ${ }^{26}$. The regulation of a club should define reasons of expiry of club membership, such as death of a councillor, expiry of councillor's mandate, exclusion from the club or accession to another club.

It is a task of the club to work out and present opinions, submit motions and opinions about draft resolutions and - in case of councillor clubs in Poland - presenting draft resolutions on important issues for a commune and a club. The main objective of operations of every club should be to act for the sake of inhabitants and the community, taking into account the subject and aim of operations of a given club.

In the Polish legal order, the regulation of a club defines forms and manner of financing of a club. These issues may be also regulated in a separate resolution of a club, if the regulation so defines. A club may not receive subsidies from the commune's budget. Clubs that achieve their objectives are entitled to submit motions and present the municipal council with opinions on draft resolutions that are subject to the discussion of the municipal council. The main tasks of a club is to represent the club's objectives by the club members in the municipal council and individual internal committees of the council. The commune's charter must not restrict club's rights resulting from the Act. Membership in a club is voluntary and it is confirmed in writing in form of a declaration. Pertaining to article $24 \mathrm{sec} .3$ of ANSG, councillors may submit oral questions and inquiries about issues related to a commune to the commune's executive body. A councillor club is not entitled to ask oral questions ${ }^{27}$. This right has been granted by the legislator to a councillor only.

26 See Jean-Bernard Auby, Jean-François Auby, and Rozen Noguellou, Droit des collectivités locales (Paris: Presses Universitaires de France - P.U.F, 2015), 139. It should be underlined that territorial communities (communes, departments, regions) are managed by councils, whose members are elected for a term of office of 6 years in direct or indirect elections.

27 The manner and result of examination of an oral question or inquiry made in the manner defined by the provisions of the Act on Municipal Self-Government are not subject to appeal in administrative courts - Provincial Administrative Court in Gorzów Wielkopolski, Judgement of 19 August 2020, Ref. No. II SAB/Go 186/20, LEX no. 3048373. 
In case of non-subordination to the club's will, e.g. when a councillor acts contradictory to the club's resolutions or in a detrimental way for the club's interests, the club's chairperson may impose sanctions defined in the regulation, such as warning, suspension of member's right for a definite period of time or removal from a club. It should be pointed out that disciplinary sanctions in clubs are allowed, contrary to the legal status of a councillor who cannot be held liable according to the provisions of the Act on Municipal Self-Government due to the institution of councillor's free mandate that is exercised. The club's regulation may introduce provisions stating that club members decide on the voting discipline during a session of the municipal council, on request of the chairperson of a club, with a respective majority of votes, e.g. with an absolute majority of votes. In particularly justified cases, the chairperson of a club shall release club members from the club's discipline.

One can ask the question whether the institution of councillor clubs in Polish communes is needed in order to pursue interests of members of local communities. If the institution of clubs correlated only with members of mandatory committees in a decision making body of local self-government, without impact on the scope of exercising of councillor's mandate, such institution is well justified in legal provisions. But an order to vote in compliance with the club's discipline that is introduced by clubs should be considered a breach of councillor's free mandate, which unfortunately often takes place in practice. It denies the idea of representation of community's interests by a given councillor.

In the French legal order, a municipal council may allocate administrative premises, office equipment to a club and cover costs related to documents, correspondence and telecom services. These issues were regulated in provisions of articles L.2121-27 et L.2121-13-1 du CGCT.

The time spent in the administrative premises, as made available to councillors, is distributed among various councillor clubs in mutual agreement. If such mutual agreement cannot be reached, a mayor distributes time in proportion to number of members of a given $\operatorname{club}^{28}$.

28 See article 33 Règlement adopté lors de la séance du Conseil municipal du 10 février 2015; https://www.fontenay-aux-roses.fr/975/reglement-interieur-du-conseil-municipal.htm. 
In result of a decision of a municipal council, a mayor may delegate one or two persons from town hall's administrative staff to assist clubs. Necessary funds are allocated in a special chapter of the municipal community's budget (but they must not be higher than $30 \%$ of the total salaries paid to the council members). It should be emphasized that the Council of the State decided that subsidies granted to councillor clubs are unacceptable. The internal regulation may define the minimum number of councillors that is necessary for establishment of a club. In communes above 3,500 inhabitants, councillors of the opposition (who are not members of any club) may have the common premises to their disposal free of charge, if they ask for it. The mayor should guarantee such premises to the opposition in or outside a town hall ${ }^{29}$. The premises should be allocated within reasonable period of time, so the opposition can exercise its rights ${ }^{30}$.

In both legal orders, councillor clubs cannot represent the decision making body in a commune in contacts with other entities. These are bodies operating within the structure of the decision making body. Clubs are represented by the chairperson of a club or another club member who is authorised to represent club interests. Public announcement of club's opinions is the expression of private opinions of its members only.

\section{CONCLUSIONS}

When determining the principles of operation of councillor clubs, the decision making body should take account article $58 \mathrm{sec}$. 1 of the Polish Constitutions that guarantees freedom of association to everybody. It means the freedom of councillors to establish clubs and associate, therefore, when determining the principles of operation of clubs, a municipal council cannot hinder the councillors' right to participate in clubs according to specific criteria, most often political or social ones ${ }^{31}$.

29 See Martine Lombard, Gilles Dumont, and Jean Sirinelli, Droit administratif (Paris: Dalloz, 2015), 176.

30 See Jacques Ferstenbert, François Priet, and Paule Quilichini, Droit des collectivités territoriales (Paris: Dalloz, 2016), 248.

31 Supreme Administrative Court, Judgement of 22 August 2013, Ref. No. II OSK 1619/13, LEX no. 1418816. 
Councillor clubs in France are used by a councillor to maintain a regular relation with inhabitants to acknowledge demands raised by them. They help a councillor to focus on the welfare of the self-governmental community, determining respect of the institution of a councillor's free mandate. This means that their aim and nature are not different than in the case of Polish councillor clubs.

Under CGCT, the French legislator more widely defined the rights of a club in respect to financial means and auxiliary apparatus necessary for club's operations than did the Polish legislator, that left those issue for determination in a commune charter and regulation of a given club.

In both legal orders, on one hand the right to establish councillor clubs derives from exercising of councillor's free mandate and it is its guarantee, but on the other hand, when a club whip is imposed in case of voting of a draft resolution, it may become a restriction in exercising of councillor's free mandate. Finding the right balance between these two planes is challenging for a responsible councillor who represents interests not only of their electorate, but mainly of the municipal community.

The amendment of 2018 strengthened the position of Polish councillor clubs both from the perspective of the regime (providing for obligatory membership of a councillor in two standing committees in the council) and from the functional perspective (granting the right to propose draft resolutions and guaranteeing a possibility to submit a draft resolution of a councillor club to the discussion of a council). These activities of the legislator should be appreciated, but they seem to be insufficient from the perspective of real strengthening of the position of councillor clubs in the self-governmental community. The French legislator did not grant the right to propose draft resolutions to clubs and left it to the commune's executive body.

A significant element of functioning of French councillor clubs is the statutory obligation to book space in the public information bulletin (Bulletin d'information générale) for expression of opinions by the opposition, in particular by clubs of opposition councillors on the conditions defined in internal regulations. This legal regulation should be appreciated. This solution may be used by the Polish legislator as an original and interesting form of the normative scope of the public information bulletin concerned. 
Both in the Polish and French legal orders, councillor clubs make it possible for councillors to present numerous initiatives, opinions, motions. Councillor clubs in a municipal council /conseil municipal may submit amendments to draft resolutions submitted in the way and on principles defined in the charter/internal regulation. Councillors belonging to clubs and non-attached councillors actively participate in works of a council and commission and may speak during a session. It strengthens the possibility of verification of activities by a councillor club, including members of a local community, which is an important element of social control.

\section{REFERENCES}

Auby, Jean-Bernadr, Auby Jean-François, and Noguellou Rozen. Droit des collectivités locales. Paris: Presses Universitaires de France - P.U.F, 2015.

Augustyniak, Monika. "O potrzebie odpolitycznienia samorządu gminnego - marzenie normatywne." Samorzad Terytorialny, no. 7-8 (2020): 44-53.

Ben Ayed, Nadia. La constitution desgroupes d'élus. Le Courrier des maires no 282 Septembre 2014, https://www.seban-associes.avocat.fr/wp-content/ uploads/2015/08/pub_cdm_groupesdelus.pdf.

Chmielnicki, Pawet. "Komentarz do art. 23." In Ustawa o samorzadzie gminnym. Komentarz, edited by Paweł Chmielnicki, 310-312. Warsaw: LexisNexis, 2010.

Ferstenbert, Jacques, Priet François, and Quilichini Paule. Droit des collectivités territoriales. Paris: Dalloz, 2016.

Lacaile, Philippe. Lélu municipal. Statut de lélu et foncionnement du conseil municipal. Paris: Berger-Levraut, 2014.

Lombard, Martine, Dumont Gilles, and Sirinelli Jean. Droit administrative. Paris: Dalloz, 2015.

Martysz, Czesław. "Komentarz do art. 23." In Ustawa o samorzadzie gminnym. Komentarz, edited by Bogdan Dolnicki, 378-381. Warsaw: Wolters Kluwer, 2018.

Potier, Vincent. Déontologie des élus et des fonctionnaires territoriaux. Paris: Dalloz, 2015.

Waline, Jean. Droit administratif. Paris: Dalloz, 2018. 